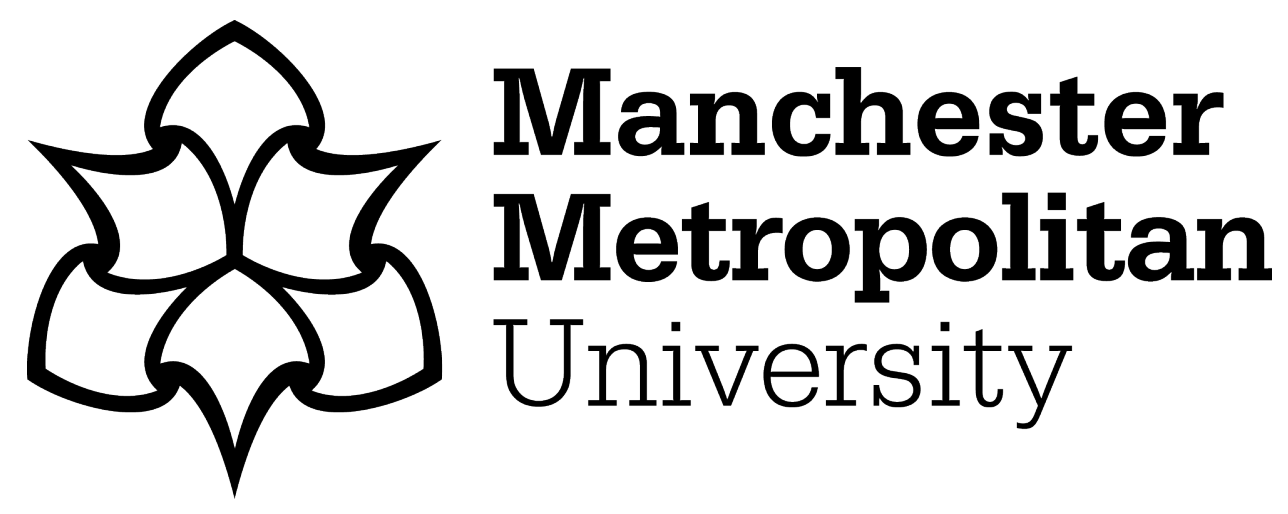

Saunders, FC and Townsend, EA (2019) Delivering new nuclear projects: a megaprojects perspective. International Journal of Managing Projects in Business, 12 (1). pp. 144-160. ISSN 1753-8378

Downloaded from: https://e-space.mmu.ac.uk/620747/

Version: Accepted Version

Publisher: Emerald

DOI: https://doi.org/10.1108/IJMPB-03-2018-0039

Usage rights: Creative Commons: Attribution-Noncommercial 4.0

Please cite the published version 


\section{Delivering New Nuclear Projects: A Megaprojects Perspective}

\begin{tabular}{|r|l|}
\hline Journal: & International Journal of Managing Projects in Business \\
\hline Manuscript ID & IJMPB-03-2018-0039.R1 \\
\hline Manuscript Type: & Research Paper \\
\hline Keywords: & Megaprojects, Case Study, Complex Projects, Planning \\
\hline \multicolumn{2}{|l}{} \\
\hline
\end{tabular}

\section{SCHOLARONE"}

Manuscripts 


\section{Delivering New Nuclear Projects: A Megaprojects Perspective}

\section{Purpose}

This conceptual paper draws on the megaprojects literature and salutary lessons from previous megaprojects to make recommendations for policymakers, promotors and project managers on how to structure and deliver new nuclear build programmes.

\section{Design/methodology/approach}

This paper is underpinned by the extant literature and an analysis of public domain data from three proposed new nuclear power plants in the UK. It identifies the main challenges facing new nuclear build projects and subsequently proposes lessons that can be learnt from megaprojects, in order to plan, structure and deliver new nuclear build programmes successfully.

\section{Findings}

The paper argues that megaprojects are simultaneously trait-making, rather than trait-taking, possess a temporality and timescale in excess of typical infrastructure projects, suffer from high levels of uncertainty and ambiguity, are organisationally complex, costly and are highly likely to destroy rather than create value. Secondly, it argues that the challenges facing new nuclear build are not merely technological but also institutional, political and societal in nature. The nature of these challenges is exemplified using three proposed new nuclear build projects in the UK.

\section{Originality/value}

This is the first paper to draw on both extant megaproject theory and on an analysis of the public domain data from three proposed new nuclear power plants in the UK. It makes 
contributions to megaprojects theory and practice, and specifically to nuclear new build projects. Importantly, it proffers recommendations for how new nuclear build programmes around the world might be structured, planned and delivered to minimise the risks of failure.

\section{Introduction}

The UK government faces an acute energy dilemma; that of accessing sources of energy that are both cheap for consumers, non-damaging to the environment and secure against geopolitical risks. An aging fleet of nuclear power plants that currently generate approximately $21 \%$ of the UK's electricity (Department of Business, 2017) are due to be decommissioned by the mid 2020's leaving a sizeable gap in the generating capacity available to the National Grid. Coupled with this, the last of the UK's coal fired power stations will go off-line around the same time (Vaughan, 2017). The options for new energy generation are three-fold: gas (either imported or from the North Sea), renewables (including solar, wind and wave power) and nuclear (through an ambitious and expensive programme of new nuclear build projects). Each of these energy options has its own strengths and weaknesses. For example, gas is cheap but risks leaving the UK increasingly reliant on imported suppliesgas. And renewables, whilst falling in price, remain unreliable as a source of stable base-load power.

Given that UK requires additional energy generation capacity before 2023, the government has made the construction of a fleet of new nuclear power plants a central pillar of its energy strategy: its argument being that nuclear power is able to provide large stable base load electricity generation, whilst supporting the drive for $\mathrm{CO} 2$ reductions. However, nuclear power comes at a financial cost (in terms of the construction of hugely complex, safe power plants and long term decommissioning and waste disposal liabilities) and concentration of risk in a small fleet of nuclear reactors (Ansar et al., 2016; Morris, 2016). 
Research into the management of complex, socio-technological projects such as nuclear power plants (Invernizzi, Locatelli, \& Brookes, 2017) has grown rapidly since the early 2000 's and there is growing traction within academic and practitioner communities for these "megaprojects" to be considered a specialised field within the wider discipline of project management (Flyvbjerg, Bruzelius and Rothengatter, 2003; Flyvbjerg, 2014b; Li et al., 2017; Pollack et al., 2017). Megaprojects are large- scale complex infrastructure projects that typically, although not exclusively, have a budget greater than US\$1Billion; take many years to plan and construct, involve multiple stakeholders and are carried out under the watchful and often critical gaze of politicians, the public and the media (Zidane, Johansen and Ekambaram, 2013; Flyvbjerg, 2014b; Mišić and Radujković, 2015). In arecent piece work(Frick, 2017), which addresses the need for the US to embark on a similarly extensive programme of infrastructure investment, Karen Trappenberg Frick eapturesarticulates the essence of megaprojects using 7 C's: colossal, captivating, costly, controversial and complex, thus requiring effective control measures and constant stakeholder communication. These characteristics of megaprojects manifest themselves as overoptimistic project forecasts coupled with underestimated risks and inadequate levels of project contingency in budgets. This leads to cost overruns, project delays and long-term benefits shortfalls or even a collapse in the long-term project viability.

Ansar et al., (2016) argue that big energy projects, such as new nuclear, are especially fragile and susceptible to technical, operational and political risks. Nuclear power plants comprise myriad interdependent components, sub-systems and systems, both to generate nuclear power in a controlled fashion and to remain safe in the event of an exhaustive set of fault scenarios. They have lengthy planning and construction horizons and are typically delivered by complicated supply chains that span numerous organisational and national cultures (Saunders, Gale, \& Sherry, 2015). The additional complexities of the UK new nuclear build 
programme were articulated clearly at the Nuclear New Build Forum in London on 20 April, 2016 as follows:

Large infrastructure projects require a range of key features and sufficient risk management to attract financing, but a new nuclear project has to go further still to draw in potential backers... New nuclear programs need to align with associated infrastructure, such as grid and transport networks, as well as develop a supply chain, receive planning consents and engage with national and local government, along with the businesses, education establishments and communities in the area the project is based. They also need to have their reactor design scrutinised by national regulators, a process that in the UK can take as long as five years. In addition, the project needs to have a fuel supply, operations, maintenance and decommissioning strategy, looking as much as 80 years ahead. (WNN, 2016)

This conceptual paper, which is based on publicly available information on the UK new nuclear build programme, argues that the challenges facing the UK's new nuclear build programme are not merely technological but also institutional, political and societal in nature. It addresses three key research questions:

1) What are megaprojects and how do they differ from traditional or non-megaprojects?

2) What are the main challenges facing new nuclear build megaprojects?

3) What lessons can policy makers, promoters and project management professionals learn from past megaprojects, in order to plan, structure and deliver the new nuclear build programme successfully?

The next section of the paper summarises the extant research into megaprojects. Subsequent sections describe the status of, and challenges facing, the UK new nuclear build programme, 
and discuss recommendations on how to most appropriately structure and deliver the UK new nuclear build programme.

\section{Megaprojects Research}

The notion of the megaproject - as an extremely complex and costly infrastructure project that attracts much public attention and has the potential to transform society - has been in existence since Selznick's (1949) study of megaproject management within the Tennessee Valley Authority in the United States. More recent megaprojects include the Channel Tunnel Fixed Rail Link, other large transportation projects such as London's Crossrail and the Edinburgh Tram Link project, bridges such as the Oresund link between Denmark and Sweden, energy projects and iconic public architecture such the Burj- Al-arab hotel in Dubai or Bilbao's Guggenheim museum. Irrespective of their particular form and function, all megaprojects involve large scale capital investments, a high level of political and public awareness and visibility and often substantial economic and environmental impact on local communities (Galloway, 2013). Flyvbjerg (2014) provides the most commonly cited formal definition of a megaproject as a "large scale complex venture that typically costs US\$1Billion or more, takes many years to develop, involves multiple public and private stakeholders, is transformational and impacts millions of people" (Flyvbjerg, 2014,p1).

Mišić \& Radujković (2015) describe megaprojects as "important drivers of society change"; a view echoed by (Zidane, Johansen and Ekambaram, 2013) who frame megaprojects as important landmarks for societies and nations. The potential for megaprojects to effect considerable societal change is, however, a double- edged sword. Politicians have often been too quick to seize on the potential of an iconic megaproject as a means of delivering a lasting, and high profile legacy (Contemporaneous examples of this in the UK alone are the planned High Speed 2 London-Birmingham Rail-link, the Edinburgh Tram project and the London 2012 Olympics). Flyvbjerg (2014) characterises this temptation as the four sublimes of 
megaprojects: The first of these is the technological sublime: the excitement and buzz of pushing the boundaries of current technology to create something innovative and spectacular. Second is the political sublime: the joy politicians get from the positive attention given by the media when starting megaprojects, and the enticing prospect of building a political legacy of iconic buildings or transport infrastructure. The third sublime is economic and is concerned with the economic benefits and job creation potential of the megaproject, coupled with the delight of engineers, architects, contractors, consultants, bankers, investors and lawyers who can enjoy the benefits of the oversized project budget. Finally, megaprojects enjoy an aesthetic sublime: the sheer pleasure of looking at something beautiful or iconic such as the London Shard building. These four sublimes can create a potent and unstoppable wave of enthusiasm for megaprojects amongst politicians, policymakers, project promoters and the public at large; irrespective of the hard truths of the colossal size of the project budget, the numerous, often downplayed risks facing the project and the questionable assumptions on which the project benefits case has been made ( see for instance: Flyvbjerg, Bruzelius, \& Rothengatter, 2003; Miller \& Lessard, 2000; van Marrewijk, Clegg, Pitsis, \& Veenswijk, 2008)

To date, much of the literature on megaprojects has been case study based, drawing on single or multiple exemplars of past megaprojects to explore and validate new ideas and theories in megaprojects. The extant literature has focussed on the political nature of funding megaprojects (strategic misrepresentation and the principle of the hidden hand) (Flyvbjerg, 2014b); front end decision making (optimism bias and the need for reference class forecasting) (Flyvbjerg, 2013; Flyvbjerg et al., 2003; Williams, 2009) the poor performance of megaprojects in terms of cost escalation, delayed delivery and benefits shortfalls (Eweje, Turner and Müller, 2012; Winch, 2013; Boateng, Chen and Ogunlana, 2015; Davies, Gann 
and Macaulay, 2017) the risks and challenges facing megaprojects (Priemus, Flyvbjerg and Wee, 2008; Sanderson, 2012; Irimia-Diéguez, Sanchez-Cazorla and Alfalla-Luque, 2014; Sanchez-cazorla, Alfalla-luque and Irimia-dieguez, 2017) and the wider consequences to society of this class of projects (Müller, 2011). More recent research has applied organisational theory to explore and explicate current practice in megaproject management. For example, (Biesenthal et al., 2017) draw on institutional theory to recommend that megaproject promoters and sponsors devote more effort to getting the institutional arrangements within the project in place before addressing the technical challenges facing the project; thereby enabling previously divergent actors, governed by different institutional rules and logics to collaborate and make sense of the emerging megaproject. Similarly Brookes, Sage, Dainty, Locatelli, \& Whyte (2017) explore the temporal nature of the megaprojects, arguing that megaprojects often outlast the Special Purpose or Joint Venture organisations that are created to deliver them.

Other recent research has mapped out the development of megaproject management as a distinct domain of project management research. Notable recent contributions to this debate have been attempts to identify the classic texts and papers in the literature on megaprojects (Flyvbjerg, 2017; Pollack et al., 2017) and bibliometric based analyses of the development of the megaprojects literature (Li et al., 2017). Both of these streams of research speak of megaprojects research reaching a tension point_crossroads in its genesis; a tipping point where the scope and aims of the field require rethinking as a prelude to reaching a theoretical consensus on what megaprojects are and how they might better be structured, governed and delivered. Li, Lu, Taylor, \& Han (2017) end their paper with a call for the megaprojects research community to pursue more interdisciplinary and multilevel studies, to better combine theory and practice to address the real-life issues confronting megaprojects and to update the classic texts to reflect and lead practitioner practices. 
Given that the McKinsey Global Institute (McKinsey and Company, 2016) predicts global infrastructure spending of US\$3.4Trillion per year between 2013-2030 mainly implemented though large scale infrastructure projects (Flyvbjerg and Turner, 2017) and that the global megaprojects market is estimated at US\$6-9Trillion per year (Flyvbjerg, 2014a) megaprojects look highly likely to remain central to society: captivating yet costly and controversial in equal measure. The question we now need to address is whether megaprojects are a distinct class of project, requiring different governance and delivery structures from those expected in more conventional projects.

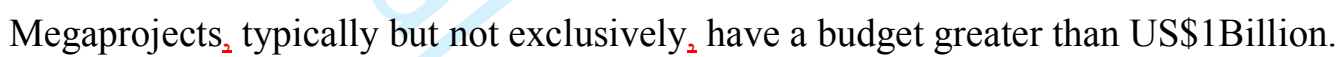
However, (Pollack et al., 2017) argue that "the real mark of a megaproject is the organisational complexity, ambiguity, ambition, politicality and risk that are entailed" (Pollack et al., 2017, p2). Given that many smaller, arguably more conventional projects also exhibit high levels of complexity, uncertainty and are highly political in nature (for example nuclear decommissioning projects), what are the features of megaprojects that distinguish them from more conventional projects? Table 1 draws on the relevant literature to highlight the key features of megaprojects and how they might be differentiated from conventional projects. It confirms the view expressed by Bent Flyvbjerg that "Megaprojects are a completely different breed of project in terms of their level of aspiration, lead times, complexity, and stakeholder involvement. Consequently, they are also a very different type of project to manage.” (Flyvbjerg, 2014b, p6)

INSERT TABLE 1 HERE

\section{The UK new nuclear build programme}

There are three planned nuclear new generation projects in the United Kingdom: Hinkley Point C in Somerset, Moorside in West Cumbria and Wylfa Newydd on the Isle of Anglesey. 
Each involves a different consortium of promoters, different reactor design technology and ${ }_{2}$ most likely ${ }_{2}$ different approaches to financing the projects.

Hinkley Point $\mathrm{C}$ is a joint UK-French venture which will be part-funded by the Chinese nuclear industry. The power plant, comprising two European Ppressurised Rreactors (EPRs), is estimated to cost $£ 19.6$ Billion (WNN, 2017b) and is expected to be in operation by the end of 2025. The EPR design aims to be safer, more reliable and more fuel efficient than its predecessor. The EPR will work in similar fashion to existing generations of the reactor; EPRs have already been approved for use in the UK, confirming the reactor meets safety requirements.

Hinkley Point $\mathrm{C}$ is the most advanced project in terms of planning and construction; the UK government gave its approval to the project on $29^{\text {th }}$ September 2016 following EDF's Final Investment Decision $28^{\text {th }}$ July 2016. Consent for the placement of the structural concrete for the first nuclear safety-related structure at the site was granted in July 2017 and the groundworks and enabling infrastructure are proceeding at pace. (WNN, 2017b)

The Moorside nuclear plant in West Cumbria-will be delivered by Nugen, currently a wholly owned subsidiary of Toshiba. Originally the Moorside site would have comprised 3 AP1000 Pressurised Water Reactors supplied by Westinghouse (Westinghouse Electric Company, 2016). Although Nugen completed its Generic Design Assessment early in 2017 (WNN, 2017a), major financial problems within Westinghouse and its parent company Toshiba led to a major strategic review of the project. In December 2017, Nugen announced that KEPCO (Korean Electrical Power Company) was the new preferred bidder for acquiring Nugen from Toshiba. KEPCO will use their own APR1400 reactor design for Moorside, and work is now underway to secure Generic Design Assessment Approval for this technology (WNN, 2017d). No date has yet been set for either Final Investment Decision or negotiation with the UK government over the strike price at which the plant output will be sold. 
The third planned nuclear power plant is Wylfa Newydd on the Isle of Anglesey in North Wales. This plant will comprise two Advanced Boiling Water Reactors (ABWRs). ABWRs are known as "direct cycle reactors" so they pass the steam straight into the turbine from the reactor rather than passing in and out of the steam generator as with the APR1400 and EPR technology (Hitachi, 2014). The Wylfa Newydd plant will be built and operated by Horizon (which is owned by Hitachi with the reactors supplied by Hitachi-GE). The ABWR remains in the regulatory assessment phase, with the earliest construction start date estimated to be 2019. (WNN, 2017f). The cost of the Wylfa Newydd project is currently estimated at $£ 20$ Billion (WNN, 2016). (Saunders, Sherry and Gale, 2016)

\section{Challenges facing the $3 \mathrm{UK}$ new nuclear build projects}

Table 2 compares the three new nuclear build projects, HPC, Moorside and Wylfa Newydd, in terms of the first 5C's of Frick's classification of megaprojects as Colossal, Captivating, Costly, Controversial and Complex (Frick, 2017). This analysis shows that the UK's new nuclear build programme faces a number of sizeable technical challenges. For instance, the sheer technical complexity of the reactor technology and the differing levels of maturity of each of the three proposed reactor designs, each of which must be assessed and approved by the Office of Nuclear Regulation before final designs can be signed off. Each site also requires extensive enabling infrastructure, from new transport and power connections to large earthworks and vast temporary accommodation blocks. Each piece of the enabling infrastructure must not only be delivered as a stand-alone project, but also contains myriad interfaces to the other enabling works and to the main reactor and turbine design and construction, thereby increasing overall programme complexity and with it the potential for increasing costs and delaying the project. These challenges are compounded by two further 
technical obstacles; that of the fragmented and fragile nature of the nuclear supply chain in the UK (Saunders, Gale, \& Sherry, 2015) and the need to simultaneously mobilise 1000's of highly-skilled workers across three remote locations in the UK. It is questionable whether sufficient of these skilled resources a) actually exist, and b) are readily available to mobilise onto a new project (typically, experienced complex project practitioners move from one megaproject to the next, e.g. from Heathrow Terminal 5 to London 2012 to CrossRail and now to the Thames Tideway Tunnel (Davies, Gann and Macaulay, 2017). In contrast, the construction phases of HPC, Moorside and Wylfa Newydd will not only overlap, but will be competing for specialist resources with other nuclear life-extension and decommissioning projects that are already underway. Anecdotal evidence from nuclear industry project professionals suggests that the solution to the resource constraints on these megaprojects will be an eventual influx of Chinese nuclear workers, rapidly and expensively mobilised to complete the projects, without allowing the UK to develop its own nuclear skills capability and capacity.

In addition to these technical challenges, Table 2 also demonstrates that many of the issues facing the projects are also institutional, societal and political in nature. The size and complexity of new nuclear build projects demands that they are delivered by multiple parties located in different parts of the globe. This introduces cross-cultural challenges into an already problematic set of complex institutional arrangements between the project promoters, the contractors, investors and the UK government (Biesenthal et al., 2017). This brings into play a huge number of organisational interfaces within the projects, each of which requires governance, contractual and behavioural mechanisms to be established, in parallel with the project definition and design phases.

At the societal and political level, national governments, local authorities and business groups are focused on the economic benefits of the project and the resultant long-term development 
of nuclear plants' hinterland. However, the mere mention of the term nuclear tends to be emotive and can lead to differences of opinion within a group of individuals and society as a whole. Opposition to nuclear technology may arise from a particular political persuasion or a deep affiliation to a green agenda. Individuals may have concerns over the safety and security aspects of nuclear and favour renewable forms of energy over nuclear, without necessary fully understanding the finer nuances of energy production economics. It is unfortunate that successive governments (not just in the UK) have had a tendency to downplay the risks associated with megaprojects and overplay the benefits that they deliver (Flyvbjerg, 2014b). This has led to a justifiable public scepticism over the proposed costs and benefits of all megaprojects, not just those in the safety-critical nuclear sector.

The financial issues with nuclear new builds, however, are not just the huge sums of money required up front, but also the many years that need to pass before there is any return of investment. This, as Table 2 shows, means a strike price is necessary to give investors' confidence in the long term financial viability of the project. Indeed the design and construction lifecycle of these nuclear megaprojects spans multiple governmental terms, an issue exacerbated by the UK's decision to serve notice on its membership of the European Union and the associated Euratom treaty which governs all aspects of nuclear cooperation and nuclear material transfers across European Union nations (Roberts, 2017).

INSERT TABLE 2 HERE

\section{Lessons for policy makers, promoters and project management professionals involved} in UK new nuclear build projects

For now, the UK government remains committed to new nuclear as a key part of its energy strategy. Although the future of Moorside is currently uncertain given the change in ownership from Toshiba to KEPCO, the construction of Hinkley Point C is officially 
underway and a final investment decision on Wylfa Newydd is expected in 2019 (WNN, 2017c). These three plants face myriad technical, institutional, societal and political challenges. The recommendations set out in Table 3 take the lessons from the megaprojects literature, with the aim of helping policy makers, promoters and project management professionals deliver Hinkley Point C, Moorside and Wylfa Newydd, whilst minimising the risk of overspend and delay on these colossal yet controversial projects. These recommendations are again structured around Frick's (2017) 5C's of megaprojects, acknowledging that these categories are not mutually exclusive and that many of the recommendations will address more than one of the $5 \mathrm{C}$ 's. For example, putting the management of risk at the heart of these projects, will counter the colossal nature of the project, as well as its complexity and cost. And, making project decision making and project data as transparent as possible should minimise the temptation for policy makers and promoters to become over-captivated by the projects and also mitigate inevitable controversy that the project generates.

Whilst the recommendations in Table 3 are grounded in the megaprojects literature and evidence from a large number of past megaprojects - both good and bad - the real challenge facing the UK's and other nuclear new build programmes is to take on board this advice sufficiently early in the projects' scoping and feasibility phases. The reality is that many of the recommendations set out in Table 3 come too late for projects such as Hinkley Point $\mathrm{C}-$ which is already underway and which, according to Morris (2016) is a financial, technical, contractual and governance "mess". It is highly unlikely that the UK government would be prepared or able to begin the procurement process for HPC again, as Morris (2016) suggests, with sunk costs on the project already into the Billions of pounds.

Additionally, there are practical limitations in a number of the recommendations. For example, as Morris (2016) argues, what is the correct reference class to use for the time and 
cost forecasting of new nuclear build projects. Past UK nuclear projects were completed $\underline{\text { decades ago in different times, using different technologies (Taylor, 2016) and worldwide }}$ those-nuclear power plants currently under construction are invariably running late and overbudget. And, how feasible is it for politicians and policy makers to hold fast to a "wait or do nothing option" as argued by (Davies, Gann and Macaulay, 2017) while energy analysts and commentators warm apocalyptically of the "lights going out in the UK by 2025 ". Finally, would any of these vast projects ever pass a final investment decision without a sense of optimism (Flyvbjerg, 2014b) that if we can put a man on the moon and contemplate travelling to Mars then we can surely build a fleet of new nuclear power stations here on Earth.

The above caveats aside the recommendations provided in Table 3 provide a framework for project scoping, delivery and decision making for worldwide new nuclear power plant construction. At the very least the recommendations provide a set of questions that promoters, policy-makers and project managers involved in these projects would be advised to take heed of. Whilst the die may be cast for Hinkley Point C, Flamanville and Olkiluoto 3, it is not too late for Moorside and Wylfa Newydd and other proposed plants around the globe that are still in the feasibility and scoping stage to learn from the literature and practice of megaprojects as described in this paper.

\section{INSERT TABLE 3 HERE}

\section{Conclusions}

This conceptual paper makes contributions to theory and practice in the domain of megaprojects, and specifically to nuclear new build projects. Theoretically the paper reviews the literature on megaprojects and synthesises a set of features of megaprojects that distinguish them from more conventional projects. We argue that megaprojects are simultaneously trait-making, rather than trait-taking, possess a temporality and timescale in 
excess of typical infrastructure projects, suffer from high levels of uncertainty and ambiguity, are organisationally complex, costly and are highly likely to destroy rather than create value. Secondly, we argue that the challenges facing new nuclear build are not merely technological but also institutional, political and societal in nature. The nature of these challenges is exemplified using the three proposed new nuclear build projects in the United Kingdom.

In terms of contributions to practice, we draw on the megaprojects literature and the lessons from previous megaprojects to proffer recommendations for how the new nuclear build programmes, both in the UK and in other regions of the world might be structured, planned and delivered to minimise the risks of failure.

The major limitation in this study is that it is based on a theoretical literature review and public domain data only. That said, there is no shortage of case study based megaprojects research which has been used to propose and validate a number of theories of megaprojects. Indeed, (Li et al., 2017) argues that the field of megaprojects research now requires more interdisciplinary and multilevel studies and studies that combine theory and practice to address the real life issues faced by mega projects. This paper contributes to this research agenda by drawing on both extant megaproject theory and the challenges facing a specific set of nuclear new build megaprojects, to propose a set of succinct recommendations for policymakers, promoters and practitioners tasked with delivering these colossal yet controversial projects.

As such, this paper lays the groundwork for future empirical research into the planning and delivery of this new generation of new nuclear build projects. A future research agenda, with proposed research questions might encompass the following areas:

Firstly, interviews with new nuclear build project policy-makers, promotors and project managers to identify the specific challenges involved in new nuclear build projects and the 
differences and similarities between new nuclear build and other megaprojects. This would

validate and extend the findings of this current conceptual paper. Secondly, further empirical

Empirical-work is now required to track the three nuclear new build projects, the extent to

which they have adopted this set of recommendations and the subsequent performance of the

projects. Such empirical studies are likely to be qualitative in nature, and utilise a number of

research methods including semi-structured interviews and ethnographic observations.

Finally, the challenges facing the nuclear sector extend beyond the provision of new nuclear

power capability. In the UK and across the globe, major nuclear decommissioning works are

underway to dismantle, make safe and return former civil nuclear sites to a clean state. Many

of these projects have budgets that are in excess of £1Billion, will span a number of decades

and involve the same complexities and uncertainties of technology, stakeholders and funding

as new nuclear build projects. Further empirical studies that specifically address the under-

researched domain of nuclear decommissioning projects would also contribute to our

conceptualisation of megaprojects, and to addressing the real life issues faced by nuclear

megaprojects over the entire nuclear lifecycle.

$\underline{\text { Acknowledgements }}$

The authors would like to take this opportunity to thank the two anonymous reviewers whose $\underline{\text { helpful and constructive comments have strengthened this paper. }}$

\section{References}

Ansar, A. et al. (2016) 'Petroleum Review', 70(834), pp. 37-40.

Biesenthal, C. et al. (2017) 'Applying institutional theories to managing megaprojects', International Journal of Project Management. Elsevier Ltd and Association for Project Management and the International Project Management Association. doi: 10.1016/j.ijproman.2017.06.006.

Boateng, P., Chen, Z. and Ogunlana, S. (2015) 'An Analytical Network Process model for risks prioritisation in megaprojects.' , International Journal of Project Management, 3(8), p. 1795-1811.

Bounds, A. (2015) 'Nuclear industry confident over long-term prospects', Financial Times. Available at: https://www.ft.com/content/a95f585a-26e6-11e5-bd83-71cb60e8f08c. 
Brookes, N. et al. (2017) 'An island of constancy in a sea of change: Rethinking project temporalities with longterm megaprojects', International Journal of Project Management. Elsevier Ltd, APM and IPMA, 35(7), pp. 1213-1224. doi: 10.1016/j.ijproman.2017.05.007.

Chapman, R. J. (2016) 'A framework for examining the dimensions and characteristics of complexity inherent within rail megaprojects', International Journal of Project Management. Elsevier Ltd and Association for Project Management and the International Project Management Association, 34(6), pp. 937-956. doi: 10.1016/j.ijproman.2016.05.001.

Chu, B. (2016) 'Why is the Hinkley Point nuclear plant so controversial?', The Independent. Available at: http://www.independent.co.uk/news/business/analysis-and-features/why-is-the-hinkley-point-nuclear-plantso-controversial-a7160781.html.

Davies, A., Gann, D. M. and Macaulay, S. C. (2017) 'Five Rules for Managing Large , Complex Projects', MIT Sloan management review.

Davies, A. and Mackenzie, I. (2014) 'Project complexity and systems integration: constructing the London 2012 Olympics and Paralympics Games', International Journal of Project Management. Elsevier Ltd, 32(5), pp. 773790. doi: 10.1016/j.ijproman.2013.10.004.

Department of Business, E. and I. S. (2017) DIGEST OF UNITED KINGDOM ENERGY STATISTICS 2017. Available at: https://www.gov.uk/government/uploads/system/uploads/attachment_data/file/633776/DUKES_2017.pdf. EDF (2016) Building Britain 's low-carbon future Our energy future. Available at: https://www.edfenergy.com/sites/default/files/hpc_building_britains_low-carbon_future_-_uly_2016.pdf.

Eduardo Yamasaki Sato, C. and De Freitas Chagas Jr, M. (2014) 'When do megaprojects start and finish? Redefining project lead time for megaproject success', International Journal of Managing Projects in Business, 7(4), p. pp.624-637. doi: https://doi.org/10.1108/IJMPB-07-2012-0040.

Eweje, J., Turner, R. and Müller, R. (2012) 'Maximizing strategic value from megaprojects: The influence of information-feed on decision-making by the project manager', International Journal of Project Management. Elsevier Ltd, 30(6), pp. 639-651. doi: 10.1016/j.ijproman.2012.01.004.

Flyvbjerg, B. (2013) 'Quality control and due diligence in project management: Getting decisions right by taking the outside view', International Journal of Project Management. Elsevier Ltd and IPMA, 31(5), pp. 760-774. doi: 10.1016/j.ijproman.2012.10.007.

Flyvbjerg, B. (2014a) 'Introduction', in Flyvbjerg, B. (ed.) Planning and Managing Megaprojects: Essential Readings Vol. 1. Cheltenham, UK and Northampton,MA: Edward Elgar, pp. xiii-xxxiv.

Flyvbjerg, B. (2014b) 'What youshould know about megaprojects and why: An overview', Project Mana, 45(2), pp. 6-19. doi: 10.1002/pmj.

Flyvbjerg, B. (2017) 'Chapter 8 Did Megaproject Research Pioneer Behavioral Economics ? The Case of Albert O . Hirschman Why Hirschman and the Hiding Hand Matter'.

Flyvbjerg, B., Bruzelius, N. and Rothengatter, W. (2003) Megaprojects and Risk:An Anatomy of Ambition. Cambridge, UK.: Cambridge University Press.

Flyvbjerg, B. and Turner, J. R. (2017) 'Do classics exist in megaproject management?', International Journal of Project Management. Elsevier Ltd. doi: 10.1016/j.ijproman.2017.07.006.

Frick, K. T. (2017) A sure bet: megaprojects- not on time not on budget. Available at: http://www.alexandrinepress.co.uk/Oakland_Bay_Bridge (Accessed: 3 October 2017).

Galloway, P. (2013) 'Part 1: Megaprojects to Gigaprojects: The way of the 21st century', in Galloway, P., Nielsen, K., and Dignum, J. (eds) Managing Gigaprojects:Advice from those who've been there and done that. 1st edn. Reston, Virginia, USA: American Society of Civil Engineers, pp. 1-3. 
Gellert, P. K. and Lynch, B. D. (2003) 'Megaprojects as displacements', International Society of Science Journal, 55(175), pp. 15-25.

Giezen, M. (2012) 'Keeping it simple? A case study into the advantages and disadvantages of reducing complexity in mega project planning', International Journal of Project Management. Elsevier Ltd, 30(7), pp. 781-790. doi: 10.1016/j.ijproman.2012.01.010.

Hirschman, A. O. (1995) Development Projects Observed. 2nd Editio. Washington,DC: Brookings Institution. Hitachi (2014) ABWR Introduction to the UK Advanced Boiling Water Reactor.

HorizonNews (2017) Horizon Nuclear Power. Available at:

http://www.horizonnuclearpower.com/news/news_details/382.

Hughes, O. (2016) “"We”Il deliver Wylfa Newydd nuclear power at fair price”, Daily Post. Available at: http://www.dailypost.co.uk/business/business-news/well-deliver-wylfa-newydd-nuclear-11664109.

Hughes, O. (2017) 'Wylfa Newydd nuclear plant could be funded by taxpayers' cash', Daily Post.

Invernizzi, D. C., Locatelli, G. and Brookes, N. (2017) 'A methodology based on benchmarking to learn across megaprojects: the case of nuclear decommissioning', International Journal of Managing Projects in Business. doi: https://doi.org/10.1108/IJMPB-05-2017-0054.

Invernizzi, D. C., Locatelli, G. and Brookes, N. J. (2017) 'Managing social challenges in the nuclear decommissioning industry: a responsible approach towards better performance - to be published in 2017', International Journal of Project Management. Elsevier Ltd and Association for Project Management and the International Project Management Association. doi: 10.1016/j.ijproman.2016.12.002.

Irimia-Diéguez, A., Sanchez-Cazorla, A. and Alfalla-Luque, R. (2014) 'Risk Management in Megaprojects.', Procedia - Social and Behavioral Sciences, 119, pp. 407-416.

Jones, L. (2017) 'Nuclear family: Hinkley Point C construction gets under way', Engineering and Technology. Available at: https://eandt.theiet.org/content/articles/2017/03/nuclear-family-hinkley-point-c-constructiongets-underway/.

Kelsey, C. (2016) Everything you need to know about Wylfa Newydd nuclear power station as Horizon opens new consultation. Available at: http://www.walesonline.co.uk/business/business-news/everything-you-needknow-wylfa-11823442.

Klakegg, O. J., Williams, T. and Shiferaw, A. T. (2015) 'Taming the "trolls": Major public projects in the making', International Journal of Project Management. Elsevier Ltd. APM and IPMA. doi: 10.1016/j.ijproman.2015.03.008.

Lakestay (2016) Moorside nuclear reactor plans and the risks to Cumbria tourism part of Lakestay. Available at: http://www.lakestay.co.uk/moorside nuclear.htm.

$\mathrm{Li}$, Y. et al. (2017) 'Bibliographic and comparative analyses to explore emerging classic texts in megaproject management', International Journal of Project Management. Elsevier Ltd and Association for Project Management and the International Project Management Association. doi: 10.1016/j.ijproman.2017.05.008.

Locatelli, G. et al. (2017) 'The Successful Delivery of Megaprojects':, Project Management Journal, 48(5), pp. 78-94.

Macadam, D. (2016) UK nuclear power station project 'in talks' for cash injection.

Macalister, T. (2014) 'Hinkley Point C: the colossus Whitehall wants but is struggling to believe in.', The Guardian. Available at: https://www.theguardian.com/business/2014/nov/20/hinkley-point-c-nuclear-plantboss-nigel-cann.

van Marrewijk, A. et al. (2008) 'Managing public-private megaprojects: Paradoxes, complexity, and project 
design', International Journal of Project Management, 26(6), pp. 591-600. doi: 10.1016/j.ijproman.2007.09.007.

McKinsey and Company (2016) Bridging Global Infrastrucutre Gaps. Available at: https://www.mckinsey.com/industries/capital-projects-and-infrastructure/our-insights/bridging-globalinfrastructure-gaps.

Merrow, E. . (1988) Understanding the outcomes of megaprojects: a quantitative analysis of very large civilian projects. Santa Monica,CA: RAND Corporation.

Miller, R. and Lessard, D. R. (2000) The Strategic Management of Large Engineering Projects: Shaping Institutions, Risks, and Governance. MIT Press.

Mišić, S. and Radujković, M. (2015) 'Critical Drivers of Megaprojects Success and Failure', Procedia Engineering, 122(December 2015), pp. 71-80. doi: 10.1016/j.proeng.2015.10.009.

Morris, P. W. G. (2016) 'Hinkley Point C : The rhetoric and the reality : Risk and the management of nuclear power projects', in Engineering Project Organising Conference. Cle Elum, Washington.

Morris, P. W. G. and Geraldi, J. G. (2011) 'Managing the institutional context for projects', Project Management Journal, 42(6), pp. 20-32.

Morris, P. W. G. and Hough, G. H. (1987) The Anatomy of Major Projects: A Study of the Reality of Project Management. Chichester, UK: Wiley.

Müller, M. (2011) 'State dirigisme in megaprojects: governing the 2014 Winter Olympics in Sochi', Environmental Planning A, 43, p. 2091-2108.

News\&Star (2016) 'Residents' concern over Moorside nuclear power station build'. Available at: http://www.newsandstar.co.uk/news/Residents-concern-over-Moorside-nuclear-power-station-build2c94b327-5c48-47a4-8112-210fee0459e6-ds.

News\&Star (2017) 'Jeremy Corbyn urged to oppose nuclear power station planned for Moorside'. Available at: http://www.newsandstar.co.uk/news/Jeremy-Corbyn-urged-to-oppose-nuclear-power-station-planned-forMoorside-30bf74c4-e216-4b83-92d3-439aacffc817-ds.

Nielsen, K., Dignum, J. and Reilly, J. (2013) 'Risk Management', in Galloway, P., Nielsen, K., and Dignum, J. (eds) Managing Gigaprojects. Virginia,USA: American Society of Civil Engineers, pp. 31-65.

NuGen (2016) Moorside: Proposed Scheme Overview. Available at: https://nugenconsultation.com/wpcontent/uploads/2016/05/Proposed-scheme.pdf.

Pollack, J. et al. (2017) 'ScienceDirect Classics in megaproject management : A structured analysis of three major works', International Journal of Project Management. Elsevier Ltd, pp. 1-13. doi: 10.1016/j.ijproman.2017.01.003.

Power-Technology (2017) 'Location of Wylfa Newydd Nuclear Power Plant'. Available at: http://www.powertechnology.com/projects/wylfa-newydd-nuclear-power-plant/wylfa-newydd-nuclear-power-plant2.html.

Priemus, H., Flyvbjerg, B. and Wee, B. (2008) Decision-making on mega-projects. Cheltenham, UK: Edward Elgar.

Roberts, D. (2017) 'What is Euratom and why does it matter?', The Guardian. Available at: https://www.theguardian.com/politics/2017/jul/10/what-is-euratom-and-why-does-it-matter.

Sanchez-cazorla, A., Alfalla-luque, R. and Irimia-dieguez, A. I. (2017) 'Risk Identification in Megaprojects as a Crucial Phase of Risk Management', Project management journal, 1(January), pp. 75-94.

Sanderson, J. (2012) 'Risk, uncertainty and governance in megaprojects: a critical discussion of alternative explanations', International Journal of Project Management. Elsevier Ltd. APM and IPMA, 30(4), pp. 432-443. 
doi: 10.1016/j.ijproman.2011.11.002.

Saunders, F. C., Gale, A. W. and Sherry, A. H. (2015) 'Conceptualising uncertainty in safety-critical projects: a practitioner perspective', International Journal of Project Management, 33(2), pp. 467-478. doi: 10.1016/j.ijproman.2014.09.002.

Saunders, F. C., Gale, A. W. and Sherry, A. H. (2016) 'Mapping the multi-faceted: determinants of uncertainty in safety-critical projects', International Journal of Project Management. Elsevier Ltd and Association for Project Management and the International Project Management Association, 34(6), pp. 1057-1070. doi: 10.1016/j.ijproman.2016.02.003.

Saunders, F. C., Sherry, A. H. and Gale, A. W. (2016) 'Dualities and dilemmas: contending with uncertainty in safety-critical projects', Construction Management and Economics. doi: http://dx.doi.org/10.1080/01446193.2016.1196824.

Selznick, P. (1949) TVA and the Grass Roots: A Study in the Sociology of Formal Organization. Berkeley, CA.: University of California Press.

Smyth, H., Lecoeuvre, L. and Vaesken, P. (2017) 'Co-creation of value and the project context: Towards application on the case of Hinkley Point C Nuclear Power Station', International Journal of Project Management. Elsevier Ltd. doi: 10.1016/j.ijproman.2017.04.013.

Taylor, S. (2016) The Fall and Rise of Nuclear Power in Britain. Cambridge, UK.: UIT.

Vaughan, A. (2017) 'Britain's last coal plant to close by 2025', The Guardian, 9 November. Available at: https://www.theguardian.com/environment/2016/nov/09/britains-last-coal-power-plants-to-close-by2025\#img-1.

Whitehaven News (2016) 'Contractor village plans for Moorside', Whitehaven News. Available at: http://www.whitehavennews.co.uk/news/Contractor-village-plans-for-Moorside-63139670-75ea-4f31-bdcd084fefa1aff7-ds.

Williams, T. (2009) 'Decisions made on scant information', in Williams, T. M., Samset, K., and Sunnevag, K. S. (eds) Making Essential Choices with Scant Information; Front End Decision Making in Projects. Basingstoke: Palgrave Macmillan., pp. 3-17.

Winch, G. M. (2013) 'Escalation in major projects: Lessons from the Channel Fixed Link', International Journal of Project Management. Elsevier B.V., pp. 1-11. doi: 10.1016/j.ijproman.2013.01.012.

WNN (2016) Attracting investors to new nuclear projects in the UK, WNN News. Available at: http://www.world-nuclear-news.org/C-Attracting-investors-to-new-nuclear-projects-in-the-UK04051601.html.

WNN (2017a) AP1000 reactor design completes UK regulatory assesment, WNN News. Available at: http://www.world-nuclear-news.org/RS-AP1000-design-completes-UK-regulatory-assessment-30031701.html.

WNN (2017b) Cost of Hinkley Point C rises by 8\%, WNN News. Available at: http://www.world-nuclearnews.org/NN-Cost-of-Hinkley-Point-C-rises-by-8-percent-EDF-says-0307175.html.

WNN (2017c) Hitachi stresses joint responsibility of UK project, WNN News. Available at: http://www.worldnuclear-news.org/C-Hitachi-stresses-joint-responsibility-of-UK-project-12061701.html.

WNN (2017d) Kepco confirmed new bidder for NuGen, WNN News. Available at: http://www.world-nuclearnews.org/C-Kepco-named-preferred-bigger-for-UKs-NuGen-07121704.html (Accessed: 18 December 2017).

WNN (2017e) National Grid puts Moorside plans on hold, WNN News. Available at: http://www.world-nuclearnews.org/NN-National-Grid-puts-Moorside-plans-on-hold-16051701.html.

WNN (2017f) Talks confirmed for Korean stake in UK Horizon project, WNN News. Available at: http://www.world-nuclear-news.org/C-Talks-confirmed-for-Korean-stake-in-UK-Horizon-nuclear-project- 
2807171.html.

Wyn-Williams, G. (2016) 'Wylfa Newydd protesters brand nuclear power "dangerous and dirty"', Daily Post. Available at: http://www.dailypost.co.uk/news/north-wales-news/wylfa-newydd-protesters-brand-nuclear12093470.

Wyn-Williams, G. (2017) 'Anglesey oil depot front runner to house thousands of Wylfa Newydd construction workers', Daily Post. Available at: http://www.dailypost.co.uk/business/business-news/anglesey-oil-depotfront-runner-12669171.

Zhai, L., Xin, Y. and Cheng, C. (2009) 'Understanding the value of project management from a stakeholder's perspective: Case study of mega-project management.', Project Management Journal, 40(1), pp. 99-109.

Zidane, Y. J.-T., Johansen, A. and Ekambaram, A. (2013) 'Megaprojects-Challenges and Lessons Learned.', in Procedia - Social and Behavioral Sciences, 74, p. 349-357. 


\section{\begin{tabular}{|l|l|l|l}
\hline Distinguishing & Description and contrast with conventional & Underpinning studies
\end{tabular} projects \\ Megaprojects}

\begin{tabular}{|l|l|}
\hline Trait-making & $\begin{array}{l}\text { Megaprojects seek to change the structure of } \\
\text { society, and can impact many thousands and } \\
\text { even millions of people. In contrast more } \\
\text { conventional projects are trait-taking, i.e., the } \\
\text { project fits within existing societal structures } \\
\text { and routines }\end{array}$ \\
\hline Temporality and & Megaproject design and construction
\end{tabular}

Timescale $\quad$ timescales can outlast governments and often the organisational or corporate structures that deliver and manage them. Criteria of success for megaprojects need to include long-term benefits

(Hirschman, 1995; Galloway, 2013; Mišić and Radujković, 2015)

(Eduardo Yamasaki Sato and De Freitas Chagas Jr, 2014; Biesenthal et al., 2017; Brookes et al., 2017)
High levels of risk, uncertainty and ambiguity

\section{Megaproject success criteria can be vague} and even misrepresented. Multiple stakeholders can increase ambiguity and uncertainty. Use of untried and novel technologies within highly complex interconnected infrastructure systems can increase risks.
(Priemus, Flyvbjerg and Wee, 2008; Nielsen, Dignum and Reilly, 2013; IrimiaDiéguez, Sanchez-Cazorla and Alfalla-Luque, 2014; Chapman, 2016; Biesenthal et al., 2017; Li et al., 2017; Sanchez-cazorla, Alfallaluque and Irimia-dieguez, 2017)

(Priemus, Flyvbjerg and Wee, 2008; Zidane, Johansen and Ekambaram, 2013; Biesenthal et al., 2017; D.C. Invernizzi, Locatelli and Brookes, 2017)

(Morris and Hough, 1987; Zhai, Xin and Cheng, 2009; Boateng, Chen and Ogunlana, 2015; Biesenthal et al., 2017) cost estimating, cost control and levels of contingency funding is reduced.

\begin{tabular}{l|l}
\hline High propensity & Due to their size, complexity and timescales
\end{tabular}
for value $\quad$ megaprojects are highly likely to experience destruction huge cost escalation and delayed delivery which can destroy value at the project, promoter, political and even national level. The megaproject may consume limited resources (people, finance, space etc) that might have been better employed elsewhere to generate value.
(Merrow, 1988; Flyvbjerg, Bruzelius and Rothengatter, 2003; Gellert and Lynch, 2003; Eweje, Turner and Müller, 2012) 


\begin{tabular}{|c|c|c|c|}
\hline Colossal & $\begin{array}{l}\text { Plant will generate } 7 \% \text { of the total } \\
\text { UK's energy needs ( Each reactor will } \\
\text { generate } 1.6 \mathrm{GW} \text { of electricity) } \\
\text { Supply chains span Europe and the } \\
\text { rest of the world. } \\
\text { Installation of } 35,000 \text { supporting } \\
\text { arrangements and } 10,000 \text { items of } \\
\text { mechanical plant (Jones, 2017) } \\
\text { Construction of } 760 \text { metre long and } \\
13.5 \text { metre high sea wall to protect } \\
\text { the plant from natural disasters (EDF, } \\
2016 \text { ) } \\
>\quad \text { One of largest and riskiest UK } \\
\text { infrastructure projects currently } \\
\text { underway (Morris, 2016) }\end{array}$ & $\begin{array}{l}\text { Project claims to be Europe's largest } \\
\text { new nuclear project, requiring a 9km } \\
\text { railway track for access (Macadam, } \\
2016 \text { ) } \\
\text { There will be three separate } \\
\text { accommodation sites covering over } \\
200 \text { acres, and providing } \\
\text { accommodation for up } 5000 \text { people } \\
\text { and car parking for almost } 1500 \text { cars } \\
\text { (Whitehaven News, 2016) } \\
\text { It will be one of largest and riskiest } \\
\text { UK infrastructure projects }\end{array}$ & $\begin{array}{l}\text { Wylfa Newydd will provide } 5.4 \text { GWe } \\
\text { of new capacity to power } 10 \text { million } \\
\text { homes starting mid 2020's. } \\
\text { Early in } 2017 \text { it was announced that } \\
\text { Anglesey's old oil depot was the "front } \\
\text { runner" to house thousands of Wylfa } \\
\text { Newydd construction workers (Wyn- } \\
\text { Williams, 2017) } \\
\text { It will be one of largest and riskiest } \\
\text { UK infrastructure projects }\end{array}$ \\
\hline Captivating & $\begin{array}{l}\text { Politically essential to UK } \\
\text { government's energy strategy } \\
\text { (Department of Business, 2017) } \\
\text { 25,000 new employment opportunities } \\
\text { created during construction } \\
>\quad \text { Peak employment around } 5,600 \\
\text { people } \\
>\quad 4 \text { million cubic metres of earth to be } \\
\text { excavated -equivalent to 1,300 } \\
\text { Olympic swimming pools } \\
>\quad 3 \text { million tonnes of concrete required } \\
-75 \text { times more concrete than in } \\
\text { Millennium Stadium in Cardiff } \\
>\quad 230,000 \text { tonnes of steel reinforcement } \\
\text { to be used (EDF, 2016) } \\
>\quad \text { The project is seen as the start up for } \\
\text { the UK becoming the "global leader" } \\
\text { in nuclear energy and is inspiring } \\
\text { young engineers and scientists. } \\
>\quad \text { Aim is to train 400 apprentices } \\
\text { (Macalister, 2014) }\end{array}$ & $\begin{array}{l}\text { Politically essential to UK } \\
\text { government's energy strategy } \\
\text { (Department of Business, 2017) } \\
\text { An estimated 6500 jobs will be } \\
\text { required during peak construction. } \\
\text { The sites may become permanent } \\
\text { features once construction is } \\
\text { complete, providing a legacy in the } \\
\text { area for the locals. (NuGen, 2016) }\end{array}$ & $\begin{array}{l}\text { Politically essential to UK } \\
\text { government's energy strategy } \\
\text { (Department of Business, 2017) } \\
4000+\text { jobs to be created during } \\
\text { construction with } 850 \text { permanent jobs } \\
\text { required post construction (Power- } \\
\text { Technology, 2017) } \\
>\quad \text { Opportunity to provide apprenticeship } \\
\text { schemes and attract young engineers } \\
\text { to the nuclear industry. } \\
\text { New partnership between Horizon } \\
\text { and Exelon towards becoming a } \\
\text { "world class nuclear operator" } \\
\text { (HorizonNews, 2017) }\end{array}$ \\
\hline
\end{tabular}




\begin{tabular}{|c|c|c|c|}
\hline Costly & $\begin{array}{l}\text { Hinkley was given an original } \\
£ 6 \text { Billion estimated cost, now } \\
\text { estimated at £19.6Billion (Smyth, } \\
\text { Lecoeuvre and Vaesken, 2017; WNN, } \\
2017 \mathrm{~b}) \\
\text { Hinkley Point C's strike price is } \\
£ 92.50 / M W h \text { (almost double the } \\
\text { current wholesale price of } \\
\text { electricity).(Jones, 2017) } \\
\text { Financial impact of likely cost and } \\
\text { schedule overruns may bankrupt an } \\
\text { already debt laden EDF (Morris, } \\
\text { 2016) }\end{array}$ & $\begin{array}{l}\text { Moorside is estimated to be a } £ 10 \\
\text { billion project, representing the largest } \\
\text { private investment project in West } \\
\text { Cumbria (NuGen, 2016) } \\
\text { This budget is expected to rise } \\
\text { considerably. } \\
\text { A guaranteed strike price has not yet } \\
\text { been confirmed, but Nugen's intention } \\
\text { is to seek a lower strike price than } \\
\text { HPC, with the investment being } \\
\text { considered a "long-term vision" } \\
\text { (Bounds, 2015) }\end{array}$ & $\begin{array}{l}\text { Wylfa Newydd is a £14 billion project } \\
\text { with hopes of delivering a "fair and } \\
\text { acceptable" strike price, below that of } \\
\text { Hinkley Point C. (Hughes, 2016) } \\
\text { There is potential for a governmental } \\
30 \% \text { equity stake in the project, with } \\
\text { ministers admitting that taxpayer's } \\
\text { money will be required to underpin } \\
\text { the project. (Hughes, 2017) }\end{array}$ \\
\hline Controversial & $\begin{array}{l}\text { Slow progress on project due to } \\
\text { Greenpeace opposition and public } \\
\text { concerns regarding the cost and long- } \\
\text { term viability of the technology } \\
\text { coupled with concerns about nuclear } \\
\text { safety post Fukushima accident. } \\
\text { Tom Burke, ex government advisor } \\
\text { and chairman of the environmental } \\
\text { pressure group E3G, argues that the } \\
\text { UK's new nuclear builds are } \\
\text { "unproven" and believes the UK is } \\
\text { following in the footsteps of previous } \\
\text { generations nuclear catastrophes. } \\
\text { (Jones, 2017) } \\
\text { Critics say that government should be } \\
\text { focussing on incentivising wind and } \\
\text { other renewables, rather than } \\
\text { subsidising new nuclear } \\
\text { Controversy over whether the UK } \\
\text { government should trust the French } \\
\text { and the Chinese companies to } \\
\text { construct this new nuclear power } \\
\text { station. (Chu, 2016) }\end{array}$ & $\begin{array}{l}\text { There are concerns over the tourism } \\
\text { legacy in the Lake District as if the } \\
\text { point of critical radioactivity is reached } \\
\text { (low risk) over half the Lake District } \\
\text { would be inaccessible for at least } 20 \\
\text { years. } \\
\text { Cumbria Tourist Board do not } \\
\text { currently support the project due to } \\
\text { fears over a Chernobyl style accident. } \\
\text { However both Cumbria County } \\
\text { Council and Guardians of the Lakes } \\
\text { National Park hold no objections to } \\
\text { the project (Lakestay, 2016) } \\
\text { Campaigners from Radiation Free } \\
\text { Lakeland have labelled the project an } \\
\text { "intolerable burden" (News\&Star, } \\
\text { 2017) } \\
\text { There is local concern over the impact } \\
\text { of the project on the road and rail } \\
\text { networks and the local health care } \\
\text { and house prices. Mirehouse } \\
\text { inhabitants heavily oppose the new } \\
\text { accommodation developments }\end{array}$ & $\begin{array}{l}\text { Amlwch town council oppose the } \\
\text { temporary accommodation camps to } \\
\text { be built in the town, preferring to } \\
\text { house workers in the former Shell oil } \\
\text { depot (Wyn-Williams, 2017). } \\
\text { PAWB (People Against Wylfa B) } \\
\text { question the Japanese firm's } \\
\text { commitment and ability to deliver this } \\
\text { project. } \\
\text { Protestors claim nuclear to be "old } \\
\text { fashioned, dangerous and dirty." } \\
\text { (Wyn-Williams, 2016) }\end{array}$ \\
\hline
\end{tabular}




\begin{tabular}{|c|c|c|c|c|}
\hline & 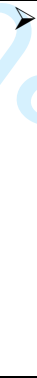 & $\begin{array}{l}\text { Critics say that strike price is bad } \\
\text { value in the current market as the } \\
\text { wholesale price of energy has } \\
\text { collapsed in the last } 3 \text { years or so, to } \\
\text { around } £ 45 \text { per megawatt hour, as } \\
\text { opposed to the } £ 92.50 \text { per megawatt } \\
\text { hour strike price for Hinkley units. } \\
\text { This potentially equals a controversial } \\
\text { cost of up to } £ 30 \text { billion on the UK } \\
\text { consumers backs (Chu, 2016) }\end{array}$ & $\begin{array}{l}\text { comparing them to "ghetto } \\
\text { camp[s]"(News\&Star, 2016). }\end{array}$ & \\
\hline Complex & $\nabla$ & $\begin{array}{l}\text { No EPR is yet in operation anywhere } \\
\text { in the world. First reactors at Olkiluoto } \\
\text { and Flamanville are hugely over- } \\
\text { budget and delayed. HPC reactor } \\
\text { design is untried and unproven } \\
\text { (Morris, 2016) } \\
\text { The first part of the complex } \\
\text { construction process involves civil } \\
\text { work and earthworks to prepare the } \\
\text { site for construction; a total of } 4 \\
\text { million square metres of earth needs } \\
\text { to be moved before construction can } \\
\text { even begin. In addition to this, } 70 \\
\text { miles of engineering and fitted pipe } \\
\text { systems are needed for each reactor. } \\
\text { It has been said that } 60 \% \text { of the } \\
\text { project is to be nuclear construction, } \\
\text { the remaining } 40 \% \text { is additional work } \\
\text { including the jetty and sea wall as well } \\
\text { as drilling tunnels for cooling pipes } \\
\text { that will go out to sea (Macalister, } \\
2014 \text { ). } \\
\text { Huge governance issues on the } \\
\text { project in particular the tension } \\
\text { between political expediency and } \\
\text { professional project management } \\
\text { practices (Morris, 2016) }\end{array}$ & $\begin{array}{l}\text { Alongside the reactor and turbine } \\
\text { buildings, support buildings including } \\
\text { a substation and a circulating water } \\
\text { system will be required. } \\
\text { Earthworks needed for screening and } \\
\text { noise reduction. Replacement } \\
\text { habitats will also be required and } \\
\text { flood plain compensation if } \\
\text { necessary. } \\
\text { Surface water, sewer drainage } \\
\text { systems and fresh groundwater } \\
\text { extraction facility required (NuGen, } \\
2016 \text { ) } \\
\text { A transport access strategy is } \\
\text { required for access to and from site; } \\
\text { this strategy will include rail and sea } \\
\text { via a marine off-loading facility, } \\
\text { extensions to the existing railway line } \\
\text { improvements to the local road } \\
\text { network (NuGen, 2016) } \\
\text { Requirement for new £2.8 billion, } \\
164 \mathrm{~km} \text { partially underground power } \\
\text { line to connect Moorside to the } \\
\text { National Grid (WNN, 2017e) }\end{array}$ & $\begin{array}{l}\text { The development consent order } \\
\text { (DCO) is scheduled for submission in } \\
2017 \text { following on from the generic } \\
\text { design assessment (GDA) of the } \\
\text { ABWR reactors which was submitted } \\
\text { in } 2014 \text {. } \\
\text { Horizon has already conducted soil } \\
\text { investigations, traffic and transport } \\
\text { surveys and ecological studies on } \\
\text { site. } \\
\text { Enabling infrastructure projects are } \\
\text { required such as the MOLF (marine } \\
\text { off-loading facility), cooling structure, } \\
\text { power transmission infrastructure and } \\
\text { administration buildings (Power- } \\
\text { Technology, 2017) } \\
\text { Project also includes } 3 \text { radioactive } \\
\text { waste storage buildings providing } \\
\text { safe and secure storage for the waste } \\
\text { onsite. When the waste can be } \\
\text { "repackaged" it will be taken to a } \\
\text { radioactive waste disposal facility } \\
\text { currently in the planning stage } \\
\text { (Kelsey, 2016). }\end{array}$ \\
\hline
\end{tabular}





Set up process for inevitable Make every effort to

design changes (whether consciously avoid

technical, institutional or

hubris/optimism bias.

Keep governmental

political) - Police this

process closely. (Flyvbjerg,

Bruzelius, \& Rothengatter,

2003)

way(Morris, 2016). communications channels

wide open and two-

Generate realistic cost

estimates, retain sufficient

contingency funds and

acknowledge the

uncertainties in nuclear

projectsy rather than

hide/ignore themit. (Flyvbjerg

et al., 2003; Klakegg et al.,

2015; Saunders, Sherry, \&

Gale, 2016)
Establish and maintain good

risk management discipline

(covering design,

construction, operation,

labour, legal, political,

contractual, financial and

economic risks) (Brookes,

Sage, Dainty, Locatelli, \&

Whyte, 2017; Sanchez-

cazorla, Alfalla-luque, \&

Irimia-dieguez, 2017)
Promote increasing

professionalism of project

organisations (Klakegg et

al., 2015)
Consider new nuclear build

as a portfolio of projects at

governmental level (phase

activities where possible to

limit strain of resources)
Reduce reliance on bespoke nuclear solutions - use scalable/modular solutions and test/pilot new technology off site first. (Ansar et al., 2016; Davies et al., 2017)

Table 33: Recommendations for policy makers, promotors and project managers for new nuclear build projects 
